\title{
The effect of non-fluoride factors on risk of dental fluorosis: Evidence from rural populations of the Main Ethiopian Rift
}

\author{
Julia Kravchenko ${ }^{\mathrm{a}, *}$, Tewodros Rango $^{\mathrm{b}}$, Igor Akushevich ${ }^{\mathrm{c}}$, Behailu Atlaw ${ }^{\mathrm{d}, \dagger}$, Peter G. McCornick ${ }^{\mathrm{e}}$, \\ R. Brittany Merola ${ }^{\mathrm{b}}$, Christopher Paul ${ }^{\mathrm{b}}$, Erika Weinthal ${ }^{\mathrm{f}}$, Courtney Harrison ${ }^{\mathrm{g}}$, Avner Vengosh ${ }^{\mathrm{b}}$, Marc Jeuland ${ }^{\mathrm{h}, \mathrm{i}}$ \\ a Duke University Medical Center, Department of Surgery, Division of Surgical Science, DUMC, Box \#3850, Duke University, Durham, NC 27710, United States \\ b Division of Earth and Ocean Sciences, Box \#90227, Nicholas School of the Environment, Duke University, Durham, NC 27708, United States \\ c Center for Population Health and Aging, Duke University, Box \#900408, Durham, NC, 27708, United States \\ d Jimma University, College of Public Health and Medical Sciences, Ethiopia \\ e International Water Management Institute, PO Box 2075, Colombo, Sri Lanka \\ ${ }^{\mathrm{f}}$ Nicholas School of the Environment, Box \#90328, A135 LSRC, Durham, NC 27708, United States \\ g Nicholas Institute for Environmental Policy Solutions, Duke University, Box \#90335, Durham, NC 27708, United States \\ h Sanford School of Public Policy, Duke University, Box \#90239, Durham, NC 27708, United States \\ i Duke Global Health Institute, Duke University, Box \#90239, Durham, NC 27708, United States
}

\section{H I G H L I G H T S}

- Fluoride is a major factor associated with dental fluorosis in Main Ethiopian Rift.

- Age, sex, and nutritional status had significant impact of dental fluorosis severity.

- Cow's milk consumption and breastfeeding could decrease severity of dental fluorosis.

- $\mathrm{Ca}, \mathrm{Al}, \mathrm{Cu}$, and $\mathrm{Rb}$ may affect dental health in those exposed to fluoride populations.

\section{A R T I C L E I N F O}

\section{Article history:}

Received 2 April 2013

Received in revised form 23 September 2013

Accepted 17 December 2013

Available online 22 January 2014

\section{Keywords:}

Fluoride

Dental fluorosis

Ethiopia

Water quality

Milk

Multiple contaminants approach

\begin{abstract}
A B S T R A C T
Elevated level of fluoride $\left(\mathrm{F}^{-}\right)$in drinking water is a well-recognized risk factor of dental fluorosis (DF). While considering optimization of region-specific standards for $\mathrm{F}^{-}$, it is reasonable, however, to consider how local diet, water sourcing practices, and non- $\mathrm{F}^{-}$elements in water may be related to health outcomes. In this study, we hypothesized that non- $\mathrm{F}^{-}$elements in groundwater and lifestyle and demographic characteristics may be independent predictors or modifiers of the effects of $\mathrm{F}^{-}$on teeth.

Dental examinations were conducted among 1094 inhabitants from 399 randomly-selected households of 20 rural communities of the Ziway-Shala lake basin of the Main Ethiopian Rift. DF severity was evaluated using the Thylstrup-Fejerskov Index (TFI). Household surveys were performed and water samples were collected from community water sources. To consider interrelations between the teeth within individual (in terms of DF severity) and between $\mathrm{F}^{-}$and non- $\mathrm{F}^{-}$elements in groundwater, the statistical methods of regression analysis, mixed models, and principal component analysis were used.

About $90 \%$ of study participants consumed water from wells with $\mathrm{F}^{-}$levels above the WHO recommended standard of $1.5 \mathrm{mg} / \mathrm{l}$. More than $62 \%$ of the study population had DF. $\mathrm{F}^{-}$levels were a major factor associated with DF. Age, sex, and milk consumption (both cow's and breastfed) were also statistically significantly $(p<0.05$ ) associated with DF severity; these associations appear both independently and as modifiers of those identified between $\mathrm{F}^{-}$ concentration and DF severity. Among 35 examined elements in groundwater, $\mathrm{Ca}, \mathrm{Al}, \mathrm{Cu}$, and $\mathrm{Rb}$ were found to be significantly correlated with dental health outcomes among the residents exposed to water with excessive $\mathrm{F}^{-}$concentrations.

Quantitative estimates obtained in our study can be used to explore new water treatment strategies, water safety and quality regulations, and lifestyle recommendations which may be more appropriate for this highly populated region.
\end{abstract}

(c) 2013 Elsevier B.V. All rights reserved.

\footnotetext{
* Corresponding author at: DUMC Box 3850, Duke University, Durham, NC 27710, United States. Tel.: +1 9196686809.

E-mail address: julia.krauchanka@duke.edu (J. Kravchenko).

$\dagger$ Behailu Atlaw passed away in 2013 before the work on this paper was completed; his contributions to the research will be missed.
} 


\section{Introduction}

An elevated level of fluoride $\left(\mathrm{F}^{-}\right)$in drinking water is a wellrecognized risk factor of dental and skeletal fluorosis, conditions which affect millions of people worldwide across many countries: e.g., in China, Mexico, India, Iran, parts of Africa, and the United States (Beltrán-Aguilar et al., 2010; Ding et al., 2011; García-Pérez et al., 2013; Hussain et al., 2010; Meyer-Lueckel et al., 2011; Ozsvath, 2006). For example, in Mexico the prevalence of fluorosis is $60.5 \%$ among residents of communities with $\mathrm{F}^{-}$level higher than $1.5 \mathrm{mg} / \mathrm{l}$ (ppm) (García-Pérez et al., 2013). In the U.S., at the beginning of the 2000s $23 \%$ of individuals aged 6-39 years old had mild or greater enamel fluorosis (BeltránAguilar et al., 2005). Although no precise numbers are reported for the global number of persons affected by fluorosis, the total for China, India, Africa, and the eastern Mediterranean populations may exceed 70 million (WHO, 2006a). Based on health hazards estimates, the World Health Organization (WHO) has established a fluoride standard for drinking water of $1.5 \mathrm{mg} / \mathrm{l}$ (WHO, 2006b). Consumption of drinking water with $\mathrm{F}^{-}$concentrations in excess of this guideline level is deemed, therefore to increase the risk of developing fluorosis, including dental fluorosis (DF). Young children appear most susceptible, given that dental enamel and skeletal formation is most active during early childhood (Buzalaf and Levy, 2011; Grobler et al., 2001).

Nonetheless, when evaluating the health effects of $\mathrm{F}^{-}-$for example, on dental tissue-at least two additional aspects should be considered. The first is that the increased concentration of $\mathrm{F}^{-}$in groundwater often correlates with concentrations of other elements, some of which may themselves be toxic or may interact with $\mathrm{F}^{-}$to increase or modify its toxicity. Such co-existence of different elements in water may arise due to the specific hydro-geological characteristics of the aquifer systems used by populations. The second is that exposure to $\mathrm{F}^{-}$does not exclusively occur through drinking water (which is generally assumed to be the principal source of $\mathrm{F}^{-}$intake), but also through dietary channels (e.g., consumption of crops or animal products with high levels of $\mathrm{F}^{-}$). For example, additional exposure to $\mathrm{F}^{-}$occurs from consuming vegetables grown in locations with high levels of naturally-occurring $\mathrm{F}^{-}$ (Poureslami et al., 2008). Tea and salt with high levels of $\mathrm{F}^{-}$can also contribute to $\mathrm{F}^{-}$intake (Mabelya et al., 1992; Cao et al., 2003). The mineral content of food, e.g., the levels of calcium and magnesium, can influence $\mathrm{F}^{-}$bioavailability due to formation of insoluble complexes (Teotia and Teotia, 1975; Cerklawski and Ridlington, 1987; Malde et al., 2004). In addition, diet and water sourcing are mediated by household behaviors, some of which may be protective (for example using water sources that are low in $\mathrm{F}^{-}$), and others may increase exposures and risks (Kaseva, 2006; Malinowska et al., 2008; Martínez-Mier et al., 2003; Viswanathan et al., 2010). In order to develop appropriate regimens and recommendations for reducing the negative impacts of $\mathrm{F}^{-}$-rich water on human health, it is thus important to understand how exposures to $\mathrm{F}^{-}$and other co-occurring natural contaminants influence the outcomes across individuals in a range of lifestyle habits.

This study reports on the results of research developed to test the hypothesis that non- $\mathrm{F}^{-}$elements in groundwater supplies and lifestyle and demographic characteristics of individuals and households may be independent predictors or modifiers of the effects of $\mathrm{F}^{-}$on dental health. We focus on dental health because it is the most prevalent indicator of high exposure to $\mathrm{F}^{-}$, in contrast to skeletal fluorosis which takes much longer to manifest in affected populations. The study was performed in 20 rural communities located in the Ziway-Shala lake basin of the Main Ethiopian Rift (MER) region. Across this zone, large rural populations are chronically exposed to a range of naturally-occurring contaminants in groundwater (Gizaw, 1996; Kilham and Hecky, 1973; Rango et al., 2009, 2010a, 2010b; Reimann et al., 2003), which is one of the main sources for drinking and cooking water.

The geological formations in the study areas are composed of young volcanic materials and fluvio-lacustrine sediments which release $\mathrm{F}^{-}$ and other toxic elements into groundwater, and the spatial distribution of these different contaminants is highly varied (Rango et al., 2012). This spatial heterogeneity presents a difficult challenge. On the one hand, consumption of MER groundwater (rather than surface water) may decrease the risks associated with microbial contamination of drinking water. Yet widespread use of this groundwater may create a range of non-infectious health hazards for local populations, of which DF may only be the easiest to identify. Without detailed information on the locations and amounts of different types of contaminants, as well as their potential interactions, it is difficult to offer clear recommendations on potential solutions to water quality problems.

In fact, it is well known that MER, and the Ziway-Shala lake basin in particular, have a very high prevalence of both dental and skeletal fluorosis (Ayenew, 2008; Haimanot et al., 1987; Kloos and Haimanot, 1999; Olsson, 1979). Moreover, despite widespread awareness of the $\mathrm{F}^{-}$problem among the water agencies in MER, rural communities have relatively limited alternatives to using wells for drinking and domestic uses, and water treatment to remove contaminants remains relatively rare. Some small-scale farmers and agricultural industries, commercial irrigators, and floriculture farms, also rely on groundwater supplies, raising the possibility of exposure via multiple channels (Rango et al., 2012). Therefore, our study focuses on some of the complexities linking an exposure to water with varied chemical characteristics to eventual health outcomes, with the goal of producing knowledge that will be valuable for achieving improvements in public health.

\section{Data and methods}

\subsection{Study population}

In this study, 1094 inhabitants from 399 randomly-selected households living in 20 communities of the Ziway-Shala lake basin of MER were examined for DF and other symptoms of fluorosis and exposure to chemical contaminants in the consumed groundwater. Of the 20 study communities, 11 were chosen from a previous sample of communities with community sources having known concentrations of $\mathrm{F}^{-}$(Rango et al., 2012). This set of communities was stratified by $\mathrm{F}^{-}$concentrations to ensure variations in exposure in our study population, and the remaining 9 communities were randomly selected from a Census of all remaining villages located in the four weredas included in our sampling frame.

The health examinations took place in December 2011-February 2012, with individuals within these households who were present at the time of the visit and gave consent to participate (or for whom a consent was given by a responsible adult in the household). An attempt was made to examine at least one adult and one child from each selected household and to ask them a series of questions related to health status, though this was not always possible. During the visit, a male or female head of the household also completed a questionnaire related to demographics and household composition; water sourcing and a range of behaviors related to water handling, storage, and treatment; general nutrition; and socio-economic characteristics (see additional details below).

Individuals in these communities consume drinking water from a variety of sources - unprotected and protected dug wells, boreholes, water taps connected to nearby towns, and surface water (lakes, rivers). The average age $( \pm S D)$ of examined individuals was $17.6 \pm 16.4$ years old, with approximately half of the population (48.8\%) being younger than 10 years old (see Table 1$)$. There were 412 (39.1\%) males and $642(60.9 \%)$ females in the sample. All individuals were examined for signs of DF (see Section 2.2) and characteristics of their nutritional status. To evaluate the latter, weight (in kilograms) and height (in meters) were measured. Then, the body mass index (BMI) was calculated $\left(\mathrm{BMI}=\right.$ weight $/$ height $^{2}$ ) for all individuals and evaluated in terms of standard normal ranges (BMI $=18.5-24.9)$, underweight $(\mathrm{BMI}<18.5)$, overweight (BMI $=25-29.9)$, and obesity $(\mathrm{BMI}>30$ ) (for individuals aged 20 years or more, as described at: http://www.cdc.gov/obesity/ 
Table 1

Demographic characteristics and lifestyle factors in the study population.

\begin{tabular}{|c|c|}
\hline Variable & Characteristic \\
\hline Number of individuals in the study, $\mathrm{N}$ & 1094 \\
\hline Age average, years ${ }^{\mathrm{a}}$ & $17.6(16.4)$ \\
\hline \multicolumn{2}{|l|}{ Age $^{\text {b: }}$} \\
\hline Individuals younger than 10 years old & $521(48.8 \%)$ \\
\hline Individuals aged 10 years old and older & $546(51.2 \%)$ \\
\hline Missed & 27 \\
\hline \multicolumn{2}{|l|}{ Gender ${ }^{\mathrm{b}}$ : } \\
\hline Males & $412(39.1 \%)$ \\
\hline Females & $642(60.9 \%)$ \\
\hline Missing & 40 \\
\hline \multicolumn{2}{|l|}{ Adults older than 20 years old, BMI, $\mathrm{kg} / \mathrm{m}^{2 \mathrm{~b}}$ : } \\
\hline$<18.5$ & $55(16.6 \%)$ \\
\hline $18.5-24.9$ & $239(72.0 \%)$ \\
\hline $25-29.9$ & $26(7.8 \%)$ \\
\hline$>30$ & $12(3.6 \%)$ \\
\hline Missing & 9 \\
\hline \multicolumn{2}{|l|}{ Frequency of consuming cow's milk ${ }^{\mathrm{b}}$ : } \\
\hline Less than once per week, & $265(25.2 \%)$ \\
\hline 1-6 times per week, & $425(40.4 \%)$ \\
\hline 7 and more times per week & $362(34.4 \%)$ \\
\hline Missing & 42 \\
\hline \multicolumn{2}{|l|}{$\begin{array}{l}\text { Number of individuals who consumed } \\
\text { water from the well with F level }{ }^{\mathrm{b}} \text { : }\end{array}$} \\
\hline$<1.5 \mathrm{mg} / \mathrm{l}$ & $112(10.2 \%)$ \\
\hline $1.5-9.9 \mathrm{mg} / \mathrm{l}$ & $850(77.7 \%)$ \\
\hline$>10 \mathrm{mg} / \mathrm{l}$ & $132(12.1 \%)$ \\
\hline \multicolumn{2}{|l|}{ Number of individuals examined for $\mathrm{DF}^{\mathrm{b}}$ : } \\
\hline No evidence of DF & $385(37.6 \%)$ \\
\hline Mild or moderate DF & $399(39.0 \%)$ \\
\hline Severe DF & $239(23.4 \%)$ \\
\hline Missing & 71 \\
\hline \multicolumn{2}{|l|}{$\begin{array}{l}\text { Number of individuals who consumed } \\
\text { water for drinking purposes from } \\
\text { the following sources }{ }^{\mathrm{b}} \text { : }\end{array}$} \\
\hline Tap & $261(23.9 \%)$ \\
\hline Protected dug well & $260(23.9 \%)$ \\
\hline Unprotected dug well & $74(6.8 \%)$ \\
\hline Borehole & $513(47.0 \%)$ \\
\hline Surface water & $127(11.7 \%)$ \\
\hline Missing & 4 \\
\hline
\end{tabular}

a Results are presented as mean (SD)

b Results are presented as number of cases (percent).

adult/defining.html). Also, to evaluate nutritional status, the subscapular skinfold thickness (SSSF) was measured three times for the nondominant arm with a skinfold caliper. The measurements were recorded to the nearest $1.0 \mathrm{~mm}$ (McDowell et al., 2008), and the mean values were used in the analyses.

\subsection{Dental health evaluation}

DF severity was evaluated based on visual interpretation of individuals' teeth (confirmed by digital images) using the Thylstrup-Fejerskov Index (TFI) which ranges from 0 (no tooth damage and normal translucence) to 9 (complete loss of a tooth) (Thylstrup and Fejerskov, 1978). The TFI was used in this analysis because it displays higher sensitivity than other indices, especially when drinking water concentrations exceed $5 \mathrm{mg} / \mathrm{l} \mathrm{of} \mathrm{F^{- }}$ (Fejerskov, 1988; Rozier, 1994), as was the case for many of the groundwater sources included in this study. During DF progression, teeth initially become chalky and opaque due to subsurface hypomineralization (scores ranging from 1 to 4 indicate increasing degree of opacity), and the teeth then develop pits and grooves due to enamel loss (scores above 5 indicate increasing loss of enamel and pitting) (Thylstrup and Fejerskov, 1978).

In this study, an individual was considered to have DF when his/her TFI score was greater than or equal to 1 . After cleaning and drying with sterile gauze of the vestibular (buccal) surfaces, the teeth were examined under natural light and scored using the TFI. Only the buccal surfaces of each tooth were examined and coded, since the literature suggests that no additional information is obtained from more extensive examination (Thylstrup and Fejerskov, 1978). Each individual was examined by one of five nurses who were trained by DF experts using visual aids, followed by the random verification of tooth scores using field checks performed by medical specialists. These visual aids displayed the ten (from 0 to 9) TFI scores corresponding to increasing DF; these also were discussed and field tested prior to actual data collection in the field. The tooth damage was considered as mild when the TFI was 1-2, moderate - with TFI 3-4, and severe when the TFI exceeded 4. Teeth with cavities or any sign of dental caries were excluded from the analysis.

The reliability of the TFI data obtained during these visual field examinations was also reassessed in a subset of 15 individuals by comparing digital photographs taken by the nurses with the assigned scores, for all teeth. Though the level of agreement between field and specialist reassessments was lower for severe DF scores above 4, linear regressions for all 172 teeth (coefficient $=0.70, \mathrm{p}<0.001 ; \mathrm{R}^{2}=0.62$ ) and 15 individual-specific mean (coefficient $=0.88, \mathrm{p}<0.001 ; \mathrm{R}^{2}=0.73$ ) DF scores showed positive and highly significant relationships; Spearman's correlation coefficients were highly significant but somewhat lower ( 0.49 and 0.60 , respectively). This level of agreement is not substantially different from that found in other work conducted by independent DF specialists in the same study region (Rango et al., 2012).

\subsection{Household and individual health questionnaire}

During the household interviews, a male or female head of the household was asked to answer the questions related to household composition, including gender and age of all household members; the sources of drinking water used by the household (such as water from the tap, protected or unprotected dug well, borehole, and from surface water sources such as lakes, rivers, and springs); estimated amounts of consumed water; dietary patterns including frequency of milk consumption (from cow or other domesticated animals); and breastfeeding history for all children.

\subsection{Human subjects: study approval}

The survey questionnaire and study design were conducted after ethical approval from the Duke University Institutional Review Board (IRB) and in accordance with the guidelines set forth by the United States Department of Health and Human Services. Permission to carry out the survey was also obtained from the Addis Ababa University and local government offices in the studied region (specifically, the water bureaus located in the four weredas where the surveys took place). The anonymity of all investigated subjects has been maintained.

\subsection{Water samples}

In addition to the household surveys and health examinations, water samples were collected from community water sources in the 20 sample communities. As described earlier by Rango et al. (2012), the concentrations of the major cations of calcium $\left(\mathrm{Ca}^{2+}\right)$, magnesium $\left(\mathrm{Mg}^{2+}\right)$, sodium $\left(\mathrm{Na}^{2+}\right)$, and silica $\left(\mathrm{SiO}_{2}\right)$ in the water were determined using Direct Current Plasma Optical Emission Spectrometry (DCP-OES). The major anions of chloride $\left(\mathrm{Cl}^{-}\right)$, sulfate $\left(\mathrm{SO}_{4}^{2-}\right)$, and nitrate $\left(\mathrm{NO}_{3}^{-}\right)$were analyzed using the method of ion chromatography. The level of $\mathrm{F}^{-}$was determined by using the ion-selective electrode (ISE). Trace element concentrations (see Table 2 for a complete list) were analyzed with a Perkin-Elmer Elan 5000 inductively coupled plasma-mass spectrometer (ICP-MS), calibrated to the National Institute of Standards and Technology (NIST) 1643e standard. 
Table 2

Associations between severity of dental fluorosis and fluoride and other elements in drinking water. ${ }^{\mathrm{a}}$

\begin{tabular}{|c|c|c|c|}
\hline Element in water & Estimate & Standard error & $\mathrm{p}$ value \\
\hline Fluoride (F), mg/l & 0.1047 & 0.0205 & $\mathrm{p}<0.0001$ \\
\hline Chloride (Cl), mg/l & 0.0119 & 0.0021 & $\mathrm{p}<0.0001$ \\
\hline Bromide (Br), mg/l & 0.5797 & 0.2057 & $\mathrm{p}=0.005$ \\
\hline Nitrate $\left(\mathrm{NO}_{3}\right), \mathrm{mg} / \mathrm{l}$ & -0.4316 & 0.1672 & $\mathrm{p}=0.01$ \\
\hline Sulfate $\left(\mathrm{SO}_{4}\right), \mathrm{mg} / \mathrm{l}$ & -0.0012 & 0.0045 & $\mathrm{p}=0.785$ \\
\hline Bicarbonate $\left(\mathrm{HCO}_{3}\right), \mathrm{mg} / \mathrm{l}$ & 0.0005 & 0.0002 & $\mathrm{p}=0.007$ \\
\hline Calcium (Ca), mg/l & 0.0138 & 0.0053 & $\mathrm{p}=0.009$ \\
\hline Magnesium (Mg), mg/l & 0.0121 & 0.0163 & $\mathrm{p}=0.456$ \\
\hline Sodium (Na), mg/l & 0.0019 & 0.0005 & $\mathrm{p}<0.0001$ \\
\hline Silica $\left(\mathrm{SiO}_{2}\right), \mathrm{mg} / \mathrm{l}$ & -0.0043 & 0.0079 & $\mathrm{p}=0.584$ \\
\hline Lithium (Li), $\mu \mathrm{g} / \mathrm{l}$ & 0.0162 & 0.0029 & $\mathrm{p}<0.0001$ \\
\hline Beryllium (Be), $\mu \mathrm{g} / \mathrm{l}$ & 1.0918 & 1.0870 & $\mathrm{p}=0.315$ \\
\hline Boron (B), $\mu \mathrm{g} / \mathrm{l}$ & 0.0005 & 0.0003 & $\mathrm{p}=0.137$ \\
\hline Zinc $(\mathrm{Zn}), \mu \mathrm{g} / \mathrm{l}$ & 0.0019 & 0.0008 & $\mathrm{p}=0.012$ \\
\hline Iron (Fe), $\mu \mathrm{g} / \mathrm{l}$ & -0.0006 & 0.0006 & $\mathrm{p}=0.297$ \\
\hline Aluminum (Al), $\mu \mathrm{g} / \mathrm{l}$ & 0.0002 & 0.0002 & $\mathrm{p}=0.283$ \\
\hline Vanadium (V), $\mu \mathrm{g} / \mathrm{l}$ & 0.0032 & 0.0048 & $\mathrm{p}=0.502$ \\
\hline Chromium (Cr), $\mu \mathrm{g} / \mathrm{l}$ & 0.0345 & 0.0129 & $\mathrm{p}=0.008$ \\
\hline Manganese (Mn), $\mu \mathrm{g} / \mathrm{l}$ & -0.0005 & 0.0006 & $\mathrm{p}=0.433$ \\
\hline Cobalt (Co), $\mu \mathrm{g} / \mathrm{l}$ & -0.2334 & 0.1357 & $\mathrm{p}=0.086$ \\
\hline Nickel (Ni), $\mu \mathrm{g} / \mathrm{l}$ & 0.0102 & 0.0402 & $\mathrm{p}=0.800$ \\
\hline Copper $(\mathrm{Cu}), \mu \mathrm{g} / \mathrm{l}$ & 0.0850 & 0.0247 & $\mathrm{p}<0.0001$ \\
\hline Arsenic (As), $\mu \mathrm{g} / \mathrm{l}$ & -0.0018 & 0.0064 & $\mathrm{p}=0.778$ \\
\hline Selenium (Se), $\mu \mathrm{g} / \mathrm{l}$ & 0.0849 & 0.0542 & $\mathrm{p}=0.117$ \\
\hline Rubidium (Rb), $\mu \mathrm{g} / \mathrm{l}$ & 0.0413 & 0.0059 & $\mathrm{p}<0.0001$ \\
\hline Strontium (Sr), $\mu \mathrm{g} / \mathrm{l}$ & 0.0015 & 0.0008 & $\mathrm{p}=0.071$ \\
\hline Molybdenum (Mo), $\mu \mathrm{g} / \mathrm{l}$ & -0.0002 & 0.0030 & $\mathrm{p}=0.939$ \\
\hline Silver $(\mathrm{Ag}), \mu \mathrm{g} / \mathrm{l}$ & -2.4913 & 1.8706 & $\mathrm{p}=0.183$ \\
\hline Cadmium (Cd), $\mu \mathrm{g} / \mathrm{l}$ & 4.4699 & 1.7385 & $\mathrm{p}=0.01$ \\
\hline Antimony (Sb), $\mu \mathrm{g} / \mathrm{l}$ & 0.6344 & 0.3995 & $\mathrm{p}=0.113$ \\
\hline Barium (Ba), $\mu \mathrm{g} / \mathrm{l}$ & -0.0114 & 0.0063 & $\mathrm{p}=0.070$ \\
\hline Thallium (Tl), $\mu \mathrm{g} / \mathrm{l}$ & 12.8219 & 2.9228 & $\mathrm{p}<0.0001$ \\
\hline Lead $(\mathrm{Pb}), \mu \mathrm{g} / \mathrm{l}$ & -0.0439 & 0.0502 & $\mathrm{p}=0.382$ \\
\hline Thorium (Th), $\mu \mathrm{g} / \mathrm{l}$ & -0.0764 & 0.6381 & $\mathrm{p}=0.905$ \\
\hline Uranium (U), $\mu \mathrm{g} / \mathrm{l}$ & 0.0191 & 0.0188 & $\mathrm{p}=0.311$ \\
\hline
\end{tabular}

a These associations are those represented by the slope parameter of the linear fit of the dependencies shown in Fig. 1.

\subsection{Methods of statistical analyses}

A spectrum of regression methods was used to conduct the multiple contaminants analysis.

First, univariate regression analysis was performed to analyze the correlation between each of the 35 elements in the water and the presence of DF among exposed individuals. The averaged TFI score was calculated for each well containing well-specific concentrations of each contaminant. Element-specific empirical plots of TFI scores vs. contaminant concentrations were then created. Using linear regression methods, linear concentration trends were estimated for each contaminant. Since TFI scores were observed for each tooth (i.e., providing up to 32 measures characterizing each person's dental health), a mixed model was used to account for the correlation in individual TFI scores across the teeth. Two types of parameters were estimated: "fixed" effects (i.e., the $\mathrm{F}^{-}$effect on DF controlling for age) and a "random" effect that reflects correlation between outcomes (i.e., tooth-specific TFI scores for an individual). The compound symmetry working matrix was used to model the correlation structure. The variable representing an individual's ingestion of $\mathrm{F}^{-}$was constructed as the product of groundwater source-specific $\mathrm{F}^{-}$concentrations within a village and the relative contributions of sources of water with high levels of $\mathrm{F}^{-}$ (i.e., dug wells and boreholes) to the total water consumption of his/ her household (via drinking and cooking).

Second, a set of two-variable regression models was used to consider how demographic (age, gender), anthropometric (BMI, SSSF), lifestyle/ dietary pattern (type and frequency of consumed milk and breastfeeding duration), and major and trace elements in the groundwater may influence the effect of $\mathrm{F}^{-}$on dental health (i.e., DF severity estimated by the TFI score) in the study population. Two separate models were considered to better understand the effects of combinations of the variables: 1) linear models in which the second variable was assumed to be an independent predictor of DF severity caused by $\mathrm{F}^{-}$( $\mathrm{F}^{-}$effect on dental status was the first variable), and, alternatively, 2) multiplicative interaction models in which the second variable was assumed to act as a modifier of the effect of $\mathrm{F}^{-}$. All of these analyses were age-adjusted by controlling for continuous age (measured in years). For multiple comparisons of the collections of such model results, the Bonferroni correction was used.

Third, a multivariable model with backward variable selection was used to analyze the joint correlation between various elements in the water and $\mathrm{F}^{-}$effects on dental tissue. For that analysis, the elements which showed statistically significant associations with DF scores in the two-variable mixed model were included in the initial specification.

In the fourth step, principal component analysis (PCA) was used to identify the principal components of multiple elements. These components were then used as independent predictors in regression analyses. PCA was used to identify the groups of elements showing the strongest associations with dental health in this population. It is important to note that the concentrations of many of the natural contaminants in groundwater are highly correlated. This step was necessary because the concentrations of many of the natural contaminants in groundwater are highly correlated.

The analyses were performed using SAS Version 9.2 (SAS institute Inc., Cary, NC).

\section{Theory and calculation}

There is widespread awareness of the $\mathrm{F}^{-}$problem among the water agencies in Ethiopia, most specifically in the Ziway-Shala basin of the MER. Despite recent investments to supply water from uncontaminated sources to the towns, the rural communities in this region still rely primarily on groundwater wells for drinking and domestic uses. For many rural communities in the MER there are no affordable water supply alternatives to groundwater and the resources required to provide all inhabitants with safe alternative water sources are unavailable. Thus, in order to develop a strategy allowing for a more effective delivery of health improvements to this area, it is important to better understand how the various elements present in the groundwater of the region interact with individual characteristics and behavior of the local residents to influence DF symptoms.

The results of this study provide some initial information on important behavioral or dietary interventions that may lead to decreases in the toxic effects of $\mathrm{F}^{-}$(e.g., associations between consumption of cow's milk or breastfeeding practice and DF). The spectrum of approaches based on the mixed models was firstly applied for estimating the effects of $\mathrm{F}^{-}$and such co-behaviors. Also, the principal components analysis may be useful for a) generating hypotheses about non- $\mathrm{F}^{-}$contaminants that may play a role in DF in this endemic zone; and b) enhancing prediction regarding "hotspots" where poor groundwater quality is of particular concern.

It is important to understand that the results presented in this paper were obtained from initial investigations of the relationships between these groundwater constituents and individuals' dental health. Further studies should be extended in three directions in order to better investigate their role in affecting dental health. First, longitudinal data collection aimed at isolating the effect of exposure to different contaminants on dental and skeletal fluorosis should be focused on individuals in the most susceptible age groups of the population (i.e., children and adolescents). Second, future studies should consider the dynamic nature of household water consumption patterns (which could vary by season and over the longer term) and map these to changing exposures and human health status. Third, future analyses should aim to obtain more complete measures of exposure to $\mathrm{F}^{-}$which would include tracking of food sources of $\mathrm{F}^{-}$in the area (e.g., cereals, dairy products, vegetables, and fruits). 


\section{Results}

\subsection{Water sources and diet in the study population}

About $90 \%$ of the study population consumed water from wells with $\mathrm{F}^{-}$levels above the standard recommended by the WHO of $1.5 \mathrm{mg} / \mathrm{l}$. Some $(12.1 \%)$ of these individuals drank water from sources with very high $\mathrm{F}^{-}$(more than $10 \mathrm{mg} / \mathrm{l}$ ). The most common sources of water used by households for drinking and household purposes were boreholes (47\%) which are the least safe in terms of toxic naturallyoccurring elements in this region (Table 1 ). Other common sources were taps (23.9\%), protected dug wells (also $23.9 \%$ ), and surface water (11.7\%). Note, that the boreholes are locally-managed pumped drilled wells, while taps refer to piped water systems managed by a nearby municipality which draws surface water from a relatively low- $\mathrm{F}^{-}$lake.

About $25 \%$ of individuals consumed milk less than once per week, while $34.4 \%$ drank it every day (Table 1 ). Cow's milk was the main animal milk consumed by the local populations. Among individuals aged 20 years or more, $72 \%$ had a normal BMI, while $16.6 \%$ were underweight and only $11.4 \%$ were overweight/obese.

\subsection{Effects of $\mathrm{F}^{-}$and other elements on dental fluorosis}

Among the examined individuals, 37.6\% had no evidence of DF, 39\% had mild or moderate DF, and $23.4 \%$ had severe DF with pitted or destructed teeth (Table 1). Simple plots of DF severity among these individuals as a function of concentration of different elements in nearby community wells are shown in Fig. 1. Note that these plots do not take into account the quantity of water that individuals drink from those particular water sources. As expected, among all elements the correlation between $\mathrm{F}^{-}$and $\mathrm{DF}$ scores is most noticeable.

The statistical significance of these correlations between different elements and TFI was further evaluated by the linear fit using weighted least squares (different points have different weights due to their different SEs). The correlations shown (Table 2) correspond to the slope parameter from a linear fit for each of the elements included in Fig. 1. In addition to $\mathrm{F}^{-}$, several elements had significant $(\mathrm{p}<0.05)$ correlations with DF severity: major elements such as $\mathrm{Cl}, \mathrm{Br}, \mathrm{NO}_{3}^{-}, \mathrm{HCO}_{3}^{-}, \mathrm{Ca}, \mathrm{Na}$, and trace elements such as $\mathrm{Li}, \mathrm{Zn}, \mathrm{Cr}, \mathrm{Cu}, \mathrm{Rb}, \mathrm{Cd}$, and $\mathrm{Tl}$. All associations were positive (i.e., higher concentrations were correlated with increased DF severity), except for $\mathrm{NO}_{3}^{-}$, for which higher concentrations were associated with lower DF. These correlations raise the possibility that several contaminants may contribute to DF. However, because the concentrations of different elements in water are highly correlated, additional multivariate analyses were performed.

\subsection{Impact of $\mathrm{F}^{-}$on dental health, accounting for demographic and lifestyle factors}

The base effect of $\mathrm{F}^{-}$on DF severity obtained from the mixed modeling approach (that accounts for correlations of DF across teeth for a single individual) indicates that the TFI score increases by 0.151 $(\mathrm{p}<0.0001)$ points on average for every $1.0 \mathrm{mg} / \mathrm{l}$ increase in concentration of $\mathrm{F}^{-}$in drinking water. In this analysis, the concentrations of $\mathrm{F}^{-}$ and other contaminants were weighted by each individual's estimated dose of exposure from groundwater for drinking and cooking purposes, as reported in the household survey (i.e., the relative amount consumed from dug wells and boreholes with high $\mathrm{F}^{-}$concentration vs. general water consumption from all sources, including those without such contaminants).

Demographic and lifestyle characteristics are also correlated with dental health outcomes (Table 3). DF severity is positively correlated with age when included as an independent factor (estimate 0.0268 , $\mathrm{p}<0.0001$ ) or as a modifier of the effect of $\mathrm{F}^{-}$(estimate 0.0041 , $\mathrm{p}<0.0001$ ). Gender is also correlated with DF outcomes: females have lower DF severity than males. BMI did not demonstrate a significant correlation with TFI, though nutritional status as measured through SSSF was associated with increasing DF severity.

Among the dietary variables considered in this study, milk consumption was the only one found to be significantly correlated with DF severity. Specifically, people who consumed cow's milk had significantly lower TFI scores, and this negative association manifested as an independent protective factor (estimate $-0.0777, \mathrm{p}=0.0031$ ) as well as a modifier of the effect of $\mathrm{F}^{-}$(estimate $-0.0107, \mathrm{p}<0.0294$ ) (Table 3). Another important source of milk intake is the duration of breastfeeding as an infant, which was considered for the 664 individuals for whom such data were collected (mostly children younger than 10 years old). As expected, the reported duration of breastfeeding (in months) when being an infant was negatively associated with DF severity, both as an independent variable (estimate $-0.0991, \mathrm{p}<0.0120$ ) and as $\mathrm{F}^{-}$effect modifier (estimate $-0.0165, \mathrm{p}<0.0368$ ). For both cow and breast-fed milk, the independent effects of consumption were more significant than their role as modifiers of the effect of $\mathrm{F}^{-}$.

To better quantify these results, we can compare the implied effects of milk on DF severity between the three different individuals of the same age, if we assume that these associations correspond to the (causal) protective effect of milk consumption. Suppose that person A does not drink cow's milk, and that the $\mathrm{F}^{-}$level in the water he consumes is $6 \mathrm{mg} / \mathrm{l}$; person B drinks cow's milk every day ( 7 times per week) and has the same $\mathrm{F}^{-}$level in his water $(6 \mathrm{mg} / \mathrm{l})$, and person $\mathrm{C}$ drinks cow's milk every day ( 7 times per week) but the $\mathrm{F}^{-}$level in his water is much higher (say, $12 \mathrm{mg} / \mathrm{l}$ ). If we consider that milk acts as an independent factor only (as in model 1 of Table 3), then the combined effect of $\mathrm{F}^{-}$and milk consumption on person A's average TFI score will be 0.90: specifically, $0.1506_{\mathrm{F}} \times 6(\mathrm{mg} / \mathrm{l})_{\mathrm{F}}-0.0777_{\text {milk }} \times 0$ (times per week $)_{\text {milk }}=0.90$. Note, that this value does not indicate individual A's average TFI score, which can only be obtained by adding the estimates of the intercept and the effect of age. For individual $\mathrm{B}$, the calculation is $0.1506_{\mathrm{F}} \times 6(\mathrm{mg} / \mathrm{l})_{\mathrm{F}}-0.0777_{\text {milk }} \times 7$ (times per week) $)_{\text {milk }}=0.36$. And for individual $\mathrm{C}$, it will be $0.1506_{\mathrm{F}} \times 12(\mathrm{mg} / \mathrm{l})_{\mathrm{F}}-0.0777_{\text {milk }} \times$ 7 (times per week $)_{\text {milk }}=1.26$. Thus, when comparing the severity of DF among these three individuals, we can attribute $0.90-0.36=$ 0.54 of the TFI score and $1.26-0.36=0.90$ of the TFI score difference between persons $A$ and $B$, and persons $C$ and $B$ respectively, to the protective effect of milk. If instead we consider milk to be a modifier of the effect of $\mathrm{F}^{-}$(as in model 2 in Table 3 ), we instead multiply it by the current $\mathrm{F}^{-}$concentration. In other words, for individual $\mathrm{A}$, we obtain $0.1897_{\mathrm{F}} \times 6(\mathrm{mg} / \mathrm{l})_{\mathrm{F}}-0.0107_{\text {milk }} \times 0(\text { times per week })_{\text {milk }} \times$ $6(\mathrm{mg} / \mathrm{l})_{\mathrm{F}}=1.14$. Using the same calculation approach we obtain estimates 0.69 and 2.20 for the other two individuals. Finally, we calculate a difference in TFI score of $1.14-0.69=0.45$ between individuals $A$ and $B$, and $2.20-1.06=1.14$ between individuals $C$ and $B$, respectively. We see that the difference between individuals does not change substantially whether milk is considered as an independent or modifying factor, thus confirming the stability of the prediction. Nonetheless, more research is needed to determine whether the correlations between milk consumption and TFI scores detected in our sample of respondents indicates a truly causal protective effect, or are actually related to some other factors that are correlated with milk consumption. For example, an experimental intervention (rather than an observational study) would be useful to determine whether milk provision affects DF outcomes.

\subsection{Analysis of the associations of other water contaminants with $D F$ outcomes}

Using the mixed model approach, the influence of the 34 water elements on dental health outcomes was analyzed in a series of twovariable models that also included $\mathrm{F}^{-}$concentration (see Table 4). Both independent (model 1) and modifying effects (model 2) of $\mathrm{F}^{-}$impact on dental health were considered. When the Bonferroni correction for multiple comparison was applied to each model, three major $(\mathrm{Cl}, \mathrm{Ca}$, 

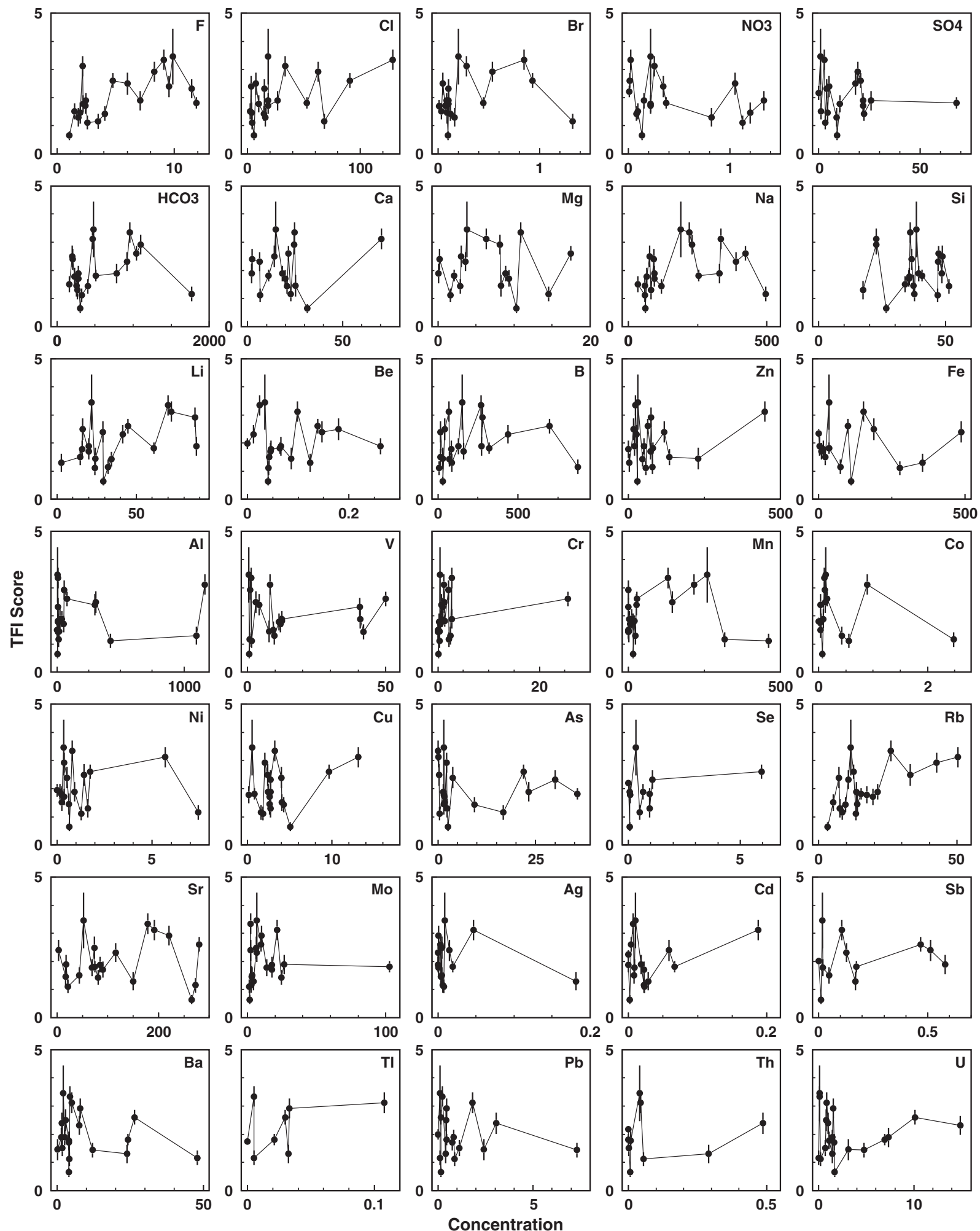

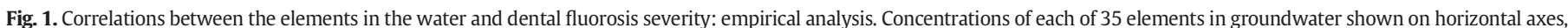

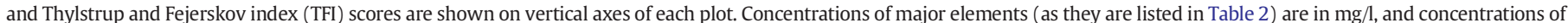
trace elements are in $\mu \mathrm{g} / \mathrm{l}$.

and $\mathrm{Mg}$ ) and nine trace ( $\mathrm{Li}, \mathrm{Zn}, \mathrm{Al}, \mathrm{Cu}, \mathrm{Rb}, \mathrm{Sr}, \mathrm{Mo}, \mathrm{Tl}$, and $\mathrm{Ba}$ ) elements showed significant associations with dental health outcomes when controlling for $\mathrm{F}^{-}$exposure. Among these elements, three $(\mathrm{Ca}, \mathrm{Cu}$, and $\mathrm{Rb})$ had independent and $\mathrm{F}^{-}$modifying associations with $\mathrm{DF}$ severity; $\mathrm{Cl}, \mathrm{Li}$, $\mathrm{Zn}$, and $\mathrm{Tl}$ had independent associations only; and $\mathrm{Mg}$, Sr, Mo, and Ba had $\mathrm{F}^{-}$modifying associations only (see Table 4). After the Bonferroni correction was also applied for two-model hypothesis, the Ca, $\mathrm{Mg}, \mathrm{Li}$, $\mathrm{Zn}, \mathrm{Al}, \mathrm{Cu}, \mathrm{Rb}$, and $\mathrm{Ba}$ associations remained significant, while the associations between $\mathrm{Cl}$ (as independent factor), and $\mathrm{Sr}$ and $\mathrm{Mo}$ (as modifiers of $\mathrm{F}^{-}$effects) and TFI scores did not retain statistical significance. Most of these elements appear positively related to DF severity, except Mo and $\mathrm{Ba}$. The results of two-variable analyses have to be interpreted with 
Table 3

Demographic and lifestyle characteristics as independent predictors of dental fluorosis severity (model 1) and as the factors modifying the effect of fluoride on the teeth (model 2).

\begin{tabular}{|c|c|c|c|c|}
\hline \multirow[t]{2}{*}{ Characteristic } & \multicolumn{2}{|c|}{ Test for being an independent predictor (model 1) } & \multicolumn{2}{|c|}{ Test for being a modifier of $\mathrm{F}^{-}$effect (model 2) } \\
\hline & Estimate for $\mathrm{F}^{-}$effect & Estimate for predictor effect & Estimate for $\mathrm{F}^{-}$effect & Estimate for modifier effect \\
\hline \multirow[t]{2}{*}{ Age, years } & 0.1499 & 0.0268 & 0.0777 & 0.0041 \\
\hline & $\mathrm{p}<0.0001$ & $\mathrm{p}<0.0001$ & $\mathrm{p}=0.0018$ & $\mathrm{p}<0.0001$ \\
\hline \multirow[t]{2}{*}{ Female gender } & 0.1480 & -0.5790 & 0.2102 & -0.1007 \\
\hline & $\mathrm{p}<0.0001$ & $\mathrm{p}=0.0001$ & $\mathrm{p}<0.0001$ & $\mathrm{p}=0.0003$ \\
\hline \multirow[t]{2}{*}{ Milk consumed, times per week } & 0.1506 & -0.0777 & 0.1897 & -0.0107 \\
\hline & $\mathrm{p}<0.0001$ & $\mathrm{p}=0.0031$ & $\mathrm{p}<0.0001$ & $\mathrm{p}=0.0294$ \\
\hline \multirow[t]{2}{*}{ BMI, $\mathrm{kg} / \mathrm{m}^{2}$} & 0.1509 & -4.0181 & 0.1511 & -0.2520 \\
\hline & $\mathrm{p}<0.0001$ & $\mathrm{p}=0.4916$ & $\mathrm{p}<0.0001$ & $\mathrm{p}=0.6475$ \\
\hline \multirow[t]{2}{*}{ Subscapular skinfold thickness, mm } & 0.1532 & 0.0479 & 0.1713 & -0.0020 \\
\hline & $\mathrm{p}<0.0001$ & $\mathrm{p}=0.0189$ & $\mathrm{p}=0.0009$ & $\mathrm{p}=0.6659$ \\
\hline \multirow[t]{2}{*}{ Breastfeeding duration as an infant, months } & 0.1204 & -0.0991 & 0.2077 & -0.0165 \\
\hline & $\mathrm{p}<0.0001$ & $\mathrm{p}=0.0120$ & $\mathrm{p}<0.0001$ & $\mathrm{p}=0.0368$ \\
\hline
\end{tabular}

Note: analyses for all variables (except of age) are age-adjusted by continuing age variable.

caution, however, because the detected associations of specific element concentrations with DF outcomes may be due to the high degree of correlation among them rather than indicating a causality.

To further explore such issues, multivariate regression analysis was applied to consider independent correlations between the elements identified above (having significant associations with TFI scores in the two-variable analyses including $\mathrm{F}^{-}$) and DF outcomes. All elements having statistically significant associations as independent predictors or modifiers were used in the initial specification of this model; elements losing significance in a multivariate model were then eliminated using backward selection. The following elements had statistically significant associations with severity of DF caused by elevated F- levels (see Table 5): Ca and $\mathrm{Al}$ (this time, in contrast to the previous analyses, these elements were negatively associated with tooth damage), and $\mathrm{Cu}$ and $\mathrm{Rb}$ (these elements were positively associated with tooth damage). Note, that there may still be the effects of interrelations between the elements in the water: e.g., $\mathrm{Ca}$ and $\mathrm{Sr}$ had mutually-related effects while performing the backward selection, and Ca only had slightly higher significance than $\mathrm{Sr}$ (and thus was retained in the final model). The correlations between the levels of certain elements in the water could explain "contradictions" between the findings on associations with DF presented in Tables 2 and 4 compared with Tables 3 and 5. For example, such "contradictions" on Ca findings can be explained as follows. In Tables 2 and 4, Ca has positive $(+)$ correlations with DF

Table 4

Major and trace elements in the water as independent predictors of dental fluorosis severity (model 1 ) and as the factors modifying the effect of fluoride on the teeth (model 2 ).

\begin{tabular}{|c|c|c|c|c|}
\hline \multirow[t]{2}{*}{ Element in the water } & \multicolumn{2}{|c|}{ Test for being an independent predictor (model 1) } & \multicolumn{2}{|c|}{ Test for being a modifier of $\mathrm{F}^{-}$effect (model 2) } \\
\hline & Estimate for $\mathrm{F}^{-}$effect & Estimate for predictor effect & Estimate for $\mathrm{F}^{-}$effect & Estimate for modifier effect \\
\hline $\mathrm{Cl}, \mathrm{mg} / \mathrm{l}$ & $0.1110, \mathrm{p}<0.0001$ & $0.0080, p=0.0015^{a}$ & $0.1109, \mathrm{p}<0.0001$ & $0.0008, p=0.0209$ \\
\hline $\mathrm{Br}, \mathrm{mg} / \mathrm{l}$ & $0.1450, \mathrm{p}<0.0001$ & $0.1419, \mathrm{p}=0.5164$ & $0.1358, \mathrm{p}<0.0001$ & $0.0378, p=0.3599$ \\
\hline $\mathrm{NO}_{3}^{-}, \mathrm{mg} / \mathrm{l}$ & $0.1522, \mathrm{p}<0.0001$ & $-0.1199, \mathrm{p}=0.5023$ & $0.1585, \mathrm{p}<0.0001$ & $-0.0313, p=0.3695$ \\
\hline $\mathrm{SO}_{4}^{2-}, \mathrm{mg} / \mathrm{l}$ & $0.1685, \mathrm{p}<0.0001$ & $-0.0081, p=0.1664$ & $0.1933, \mathrm{p}<0.0001$ & $-0.0016, p=0.0042$ \\
\hline $\mathrm{HCO}_{3}^{-}, \mathrm{mg} / \mathrm{l}$ & $0.1403, \mathrm{p}<0.0001$ & $0.0002, \mathrm{p}=0.3955$ & $0.0983, \mathrm{p}=0.0023$ & $0.0001, \mathrm{p}=0.0407$ \\
\hline $\mathrm{Ca}, \mathrm{mg} / \mathrm{l}$ & $0.1576, \mathrm{p}<0.0001$ & $0.0272, \mathrm{p}<0.0001^{\mathrm{a}, \mathrm{b}}$ & $0.0819, \mathrm{p}=0.0020$ & $0.0068, \mathrm{p}<0.0001^{\mathrm{a}, \mathrm{b}}$ \\
\hline $\mathrm{Mg}, \mathrm{mg} / \mathrm{l}$ & $0.1530, \mathrm{p}<0.0001$ & $0.0484, p=0.0024$ & $0.1146, \mathrm{p}<0.0001$ & $0.0111, \mathrm{p}=0.0004^{\mathrm{a}, \mathrm{b}}$ \\
\hline $\mathrm{Na}, \mathrm{mg} / \mathrm{l}$ & $0.1244, \mathrm{p}<0.0001$ & $0.0012, \mathrm{p}=0.0401$ & $0.1117, \mathrm{p}=0.0024$ & $0.0002, \mathrm{p}=0.2146$ \\
\hline $\mathrm{SiO}_{2}, \mathrm{mg} / \mathrm{l}$ & $0.1477, \mathrm{p}<0.0001$ & $0.0008, p=0.8762$ & $0.1954, \mathrm{p}=0.0016$ & $-0.0012, p=0.4380$ \\
\hline $\mathrm{Li}, \mu \mathrm{g} / \mathrm{l}$ & $0.0620, p=0.0255$ & $0.0169, \mathrm{p}<0.0001^{\mathrm{a}, \mathrm{b}}$ & $0.0625, \mathrm{p}=0.1094$ & $0.0015, \mathrm{p}=0.0092$ \\
\hline $\mathrm{Be}, \mu \mathrm{g} / \mathrm{l}$ & $0.1417, \mathrm{p}<0.0001$ & $2.2103, \mathrm{p}=0.0377$ & $0.1509, \mathrm{p}<0.0001$ & $-0.0168, p=0.9392$ \\
\hline $\mathrm{B}, \mu \mathrm{g} / \mathrm{l}$ & $0.1503, \mathrm{p}<0.0001$ & $-0.00001, p=0.9690$ & $0.1492, \mathrm{p}<0.0001$ & $0.000003, p=0.9711$ \\
\hline $\mathrm{Zn}, \mu \mathrm{g} / \mathrm{l}$ & $0.1467, \mathrm{p}<0.0001$ & $0.0030, p=0.0003^{\mathrm{a}, \mathrm{b}}$ & $0.1327, \mathrm{p}<0.0001$ & $0.0003, p=0.2814$ \\
\hline $\mathrm{Fe}, \mu \mathrm{g} / \mathrm{l}$ & $0.1582, \mathrm{p}<0.0001$ & $-0.0010, p=0.1198$ & $0.1637, \mathrm{p}<0.0001$ & $-0.0001, p=0.0969$ \\
\hline $\mathrm{Al}, \mu \mathrm{g} / \mathrm{l}$ & $0.1491, \mathrm{p}<0.0001$ & $0.0011, \mathrm{p}=0.0007^{\mathrm{a}, \mathrm{b}}$ & $0.1393, \mathrm{p}<0.0001$ & $0.0002, \mathrm{p}=0.0734$ \\
\hline $\mathrm{V}, \mu \mathrm{g} / \mathrm{l}$ & $0.1356, \mathrm{p}<0.0001$ & $0.0136, p=0.0186$ & $0.1357, \mathrm{p}<0.0001$ & $0.0011, p=0.2279$ \\
\hline $\mathrm{Cr}, \mu \mathrm{g} / \mathrm{l}$ & $0.1423, \mathrm{p}<0.0001$ & $0.0432, p=0.0062$ & $0.1336, \mathrm{p}<0.0001$ & $0.0093, p=0.0091$ \\
\hline $\mathrm{Mn}, \mu \mathrm{g} / \mathrm{l}$ & $0.1500, \mathrm{p}<0.0001$ & $-0.0008, p=0.1710$ & $0.1542, \mathrm{p}<0.0001$ & $-0.0001, p=0.4003$ \\
\hline Co, $\mu \mathrm{g} / \mathrm{l}$ & $0.1488, \mathrm{p}<0.0001$ & $-0.1963, p=0.1400$ & $0.1519, \mathrm{p}<0.0001$ & $-0.0671, \mathrm{p}=0.0856$ \\
\hline $\mathrm{Ni}, \mu \mathrm{g} / \mathrm{l}$ & $0.1501, \mathrm{p}<0.0001$ & $0.0295, \mathrm{p}=0.4598$ & $0.1490, \mathrm{p}<0.0001$ & $0.0027, p=0.8255$ \\
\hline $\mathrm{Cu}, \mu \mathrm{g} / \mathrm{l}$ & $0.1381, \mathrm{p}<0.0001$ & $0.1358, \mathrm{p}<0.0001^{\mathrm{a}, \mathrm{b}}$ & $0.0605, \mathrm{p}=0.0202$ & $0.0407, \mathrm{p}<0.0001^{\mathrm{a}, \mathrm{b}}$ \\
\hline As, $\mu \mathrm{g} / \mathrm{l}$ & $0.1864, \mathrm{p}<0.0001$ & $-0.0231, p=0.0104$ & $0.1986, \mathrm{p}<0.0001$ & $-0.0028, p=0.0037$ \\
\hline Se, $\mu \mathrm{g} / \mathrm{l}$ & $0.1458, \mathrm{p}<0.0001$ & $0.1059, \mathrm{p}=0.1093$ & $0.1463, \mathrm{p}<0.0001$ & $0.0078, p=0.5762$ \\
\hline $\mathrm{Rb}, \mu \mathrm{g} / \mathrm{l}$ & $0.0982, \mathrm{p}<0.0001$ & $0.0321, \mathrm{p}<0.0001^{\mathrm{a}, \mathrm{b}}$ & $0.0637, \mathrm{p}=0.0286$ & $0.0045, \mathrm{p}<0.0001^{\mathrm{a}, \mathrm{b}}$ \\
\hline $\mathrm{Sr}, \mu \mathrm{g} / \mathrm{l}$ & $0.1361, \mathrm{p}<0.0001$ & $0.0020, p=0.0152$ & $0.0970, p=0.0002$ & $0.0005, p=0.0018^{a}$ \\
\hline Mo, $\mu \mathrm{g} / \mathrm{l}$ & $0.1701, \mathrm{p}<0.0001$ & $-0.0070, p=0.0780$ & $0.1894, \mathrm{p}<0.0001$ & $-0.0011, p=0.0015^{a}$ \\
\hline $\mathrm{Ag}, \mu \mathrm{g} / \mathrm{l}$ & $0.1429, \mathrm{p}<0.0001$ & $14.3818, \mathrm{p}=0.0601$ & $0.1822, \mathrm{p}<0.0001$ & $-3.8896, p=0.0143$ \\
\hline $\mathrm{Cd}, \mu \mathrm{g} / \mathrm{l}$ & $0.1414, \mathrm{p}<0.0001$ & $4.7848, p=0.0133$ & $0.1744, \mathrm{p}<0.0001$ & $-0.8049, \mathrm{p}=0.0642$ \\
\hline $\mathrm{Sb}, \mu \mathrm{g} / \mathrm{l}$ & $0.1401, \mathrm{p}<0.0001$ & $0.4858, p=0.3258$ & $0.1594, \mathrm{p}<0.0001$ & $-0.0474, p=0.4759$ \\
\hline $\mathrm{Ba}, \mu \mathrm{g} / \mathrm{l}$ & $0.1627, \mathrm{p}<0.0001$ & $-0.0157, \mathrm{p}=0.0190$ & $0.1968, \mathrm{p}<0.0001$ & $-0.0045, \mathrm{p}=0.0006^{\mathrm{a}, \mathrm{b}}$ \\
\hline $\mathrm{Tl}, \mu \mathrm{g} / \mathrm{l}$ & $0.1390, \mathrm{p}<0.0001$ & $16.0498, \mathrm{p}<0.0001^{\mathrm{a}}$ & $0.1229, \mathrm{p}<0.0001$ & $2.4381, \mathrm{p}=0.0086$ \\
\hline $\mathrm{Pb}, \mu \mathrm{g} / \mathrm{l}$ & $0.1494, \mathrm{p}<0.0001$ & $0.0128, p=0.8362$ & $0.1601, \mathrm{p}<0.0001$ & $-0.0138, p=0.2314$ \\
\hline Th, $\mu \mathrm{g} / \mathrm{l}$ & $0.1588, \mathrm{p}<0.0001$ & $-0.9848, p=0.1843$ & $0.1598, \mathrm{p}<0.0001$ & $-0.1088, p=0.1651$ \\
\hline $\mathrm{U}, \mu \mathrm{g} / \mathrm{l}$ & $0.1409, \mathrm{p}<0.0001$ & $0.0196, p=0.4467$ & $0.1554, \mathrm{p}<0.0001$ & $-0.0011, p=0.7283$ \\
\hline
\end{tabular}

Notes: Analyses for all variables (except of age) are age-adjusted by continuing age variable.

a Significant under the Bonferroni correction for multiple comparisons.

b Significant $(\mathrm{p}<0.05)$ for two-models (independent and modifying) hypothesis. 
Table 5

Statistically significant associations between the tested elements and DF severity; multivariate analysis.

\begin{tabular}{lrll}
\hline Parameter & Estimate & Standard error & $\mathrm{p}$ value \\
\hline Intercept & 0.4917 & 0.1691 & $\mathrm{p}=0.004$ \\
Age & 0.0228 & 0.0046 & $\mathrm{p}<0.0001$ \\
$\mathrm{~F}, \mathrm{mg} / \mathrm{l}$ & 0.0787 & 0.0267 & $\mathrm{p}=0.003$ \\
$\mathrm{Ca}, \mathrm{mg} / \mathrm{l}$ & -0.0255 & 0.0115 & $\mathrm{p}=0.027$ \\
$\mathrm{Cu}, \mu \mathrm{g} / \mathrm{l}$ & 0.2291 & 0.0518 & $\mathrm{p}<0.0001$ \\
$\mathrm{Rb}, \mu \mathrm{g} / \mathrm{l}$ & 0.0492 & 0.0105 & $\mathrm{p}<0.0001$ \\
$\mathrm{Al}, \mu \mathrm{g} / \mathrm{l}$ & -0.0013 & 0.0005 & $\mathrm{p}=0.005$ \\
\hline
\end{tabular}

scores (i.e., potentially exacerbating "damaging" effects of $\mathrm{F}^{-}$on teeth). However, Table 3 shows a negative ( - ) associations between milk consumption and DF among the residents exposed to higher levels of $\mathrm{F}^{-}$in the water. This seems not to be in an agreement with the results showed in Tables 2 and 4, because milk is known to be a reach source of Ca. However, these "contradictions" can be explained when taking onto account the correlations between $\mathrm{Ca}$ and several other elements in the water in these wells: for example, correlation coefficients for $\mathrm{Rb}$ and $\mathrm{Cu}$ are 0.6 and 0.72 , respectively. In fact, that becomes more evident in the multivariate analysis (as shown in Table 5): in this analysis, $\mathrm{Ca}$ shows a negative $(-)$ correlation with DF scores, thus being in an agreement with our findings on "protective" effect of milk.

The issue of correlation across water elements serves to motivate additional modeling using principal component analysis. Among the strongest and most statistically significant correlations (an absolute value of the Pearson correlation coefficient is $>0.5, \mathrm{p}<0.001$ ) are: $\mathrm{F}^{-}$ and $\mathrm{Li}(\mathrm{r}=0.56), \mathrm{F}^{-}$and $\mathrm{As}(\mathrm{r}=0.61), \mathrm{F}^{-}$and $\mathrm{U}(\mathrm{r}=0.5), \mathrm{Cl}$ and $\mathrm{Br}$ $(\mathrm{r}=0.86), \mathrm{Br}$ and $\mathrm{HCO}_{3}^{-}(\mathrm{r}=0.87), \mathrm{SO}_{4}^{2-}$ and $\mathrm{Mo}(\mathrm{r}=0.92)$, and $\mathrm{Ca}$ and $\mathrm{SiO}_{2}(\mathrm{r}=-0.67)$. Applying PCA yielded six principal components (PCs) that together represent $82.3 \%$ of the variation in the composition of water. The following elements predominantly contribute to these components:

$$
\begin{aligned}
& \text { PC1 (24.3\%): } 0.31 \cdot \mathrm{B}+0.31 \cdot \mathrm{Br}+0.30 \cdot \mathrm{Na}+0.30 \cdot \mathrm{HCO}_{3}^{-}+0.27 \cdot \mathrm{Sr} \\
& +0.27 \cdot \mathrm{Ba}+0.26 \cdot \mathrm{Cl}+\ldots \\
& \text { PC2 (21.7\%): } \quad 0.32 \cdot \mathrm{Al}+0.30 \cdot \mathrm{Zn}+0.30 \cdot \mathrm{Ca}+0.27 \cdot \mathrm{Cd}+0.27 \cdot \mathrm{Tl} \\
& +0.27 \cdot \mathrm{Ag}+\ldots \text {; } \\
& \text { PC3 (13.1\%): } \quad 0.30 \cdot \mathrm{Sb}+0.28 \cdot \mathrm{Mo}+0.27 \cdot \mathrm{Cd}+0.26 \cdot \mathrm{Ag}+0.26 \cdot \mathrm{U} \\
& +0.25 \cdot \mathrm{As}+0.24 \cdot \mathrm{SO}_{4}^{2-}+0.24 \cdot \mathrm{V}+\ldots \text {; } \\
& \text { PC4 (9.4\%): } \quad 0.33 \cdot \mathrm{Fe}+0.30 \cdot \mathrm{Li}+0.27 \cdot \mathrm{Cr}+0.27 \cdot \mathrm{Mo}+0.27 \cdot \mathrm{Se} \\
& +0.25 \cdot \mathrm{Si}+0.25 \cdot \mathrm{Rb}+\ldots \text {; } \\
& \text { PC5 (8.6\%): } \quad 0.34 \cdot \mathrm{Co}+0.33 \cdot \mathrm{Mn}+0.26 \cdot \mathrm{Cu}+0.25 \cdot \mathrm{Mg}+0.24 \cdot \mathrm{Ba} \\
& +0.23 \cdot \mathrm{Ni}+\ldots \text {; } \\
& \text { PC6 (5.3\%): } \quad 0.48 \cdot \mathrm{Th}+0.36 \cdot \mathrm{F}+0.30 \cdot \mathrm{Fe}+0.27 \cdot \mathrm{Sb}+0.27 \cdot \mathrm{Li} \\
& +0.23 \cdot \mathrm{Mo}+0.23 \cdot \mathrm{Cl}+\ldots .
\end{aligned}
$$

\section{Table 6}

Estimates of TFI scores when the principal components are used in the mixed model as predictors.

\begin{tabular}{lrll}
\hline Effect & Estimate & Standard error & $\mathrm{p}$ value \\
\hline Intercept & 1.6630 & 0.1160 & $\mathrm{p}<0.0001$ \\
Age & 0.0252 & 0.0047 & $\mathrm{p}<0.0001$ \\
Principal component 1 & 0.0745 & 0.0269 & $\mathrm{p}=0.006$ \\
Principal component 2 & 0.0602 & 0.0281 & $\mathrm{p}=0.032$ \\
Principal component 3 & 0.1243 & 0.0368 & $\mathrm{p}<0.0001$ \\
Principal component 4 & -0.0892 & 0.0431 & $\mathrm{p}=0.039$ \\
Principal component 5 & -0.1339 & 0.0453 & $\mathrm{p}=0.003$ \\
Principal component 6 & 0.2876 & 0.0573 & $\mathrm{p}<0.0001$ \\
\hline
\end{tabular}

The percents in the parentheses show the fraction of total variants explained by a given component. Numeric coefficients at the elements denote their weights (or loadings). The complete set of the weights is presented in Supplemental Table 1. Note, that $\mathrm{F}^{-}$presents itself in all principal components; however its contribution was greatest in the sixth component.

Once these six independent components were identified, they were used in the mixed model to explain the variations in TFI scores. This allows us to reduce bias associated with highly correlated predictors that is present in the preceding analyses. The results from the PCA analysis are presented in Table 6. The effects of all six normalized principal components (i.e., with zero mean and unit standard deviation) are estimated as significant. Under this normalization, the coefficient estimates for each principal component indicate the change in TFI score that corresponds to one standard deviation change in its value. The intercept term and the age variable coefficient can be applied to indicate the TFI score for an individual of a particular age consuming the water that has the average sample concentration of the different elements. As expected, the strongest effect on DF outcomes arises from component 6 , where $\mathrm{F}^{-}$is a major contributor.

\subsubsection{Sensitivity analysis}

The effects of two assumptions on statistical significance and estimated relationships were tested in sensitivity analysis: whether a) explicit modeling of a multistage cluster sample (accounting for loss of power due to community and household-level correlation), and b) other approaches to age-specific analyses (which could result in bias).

More specifically, the inclusion of several family members from each sample household represents an additional cluster in the data. We updated the mixed model used for the base analyses to reflect this additional source of correlation. As expected, this resulted in decreased statistical power and larger standard errors, yet there were few notable changes with regard to the statistical significance of the original estimates of the model parameters. In particular, associations between $\mathrm{F}^{-}$levels and DF severity (controlled by age) remained the same $(0.145 \pm 0.026, \mathrm{p}<0.0001)$. Note, assuming an additional common correlation at the level of communities (i.e., villages) resulted in close estimates of the effect of $\mathrm{F}^{-}(0.158 \pm 0.034, \mathrm{p}<0.0001)$. The effect of milk (in Table 3 ) is also stable: the results for model 1 became $-0.0656, p=0.0353$ for the estimate of predictor effect, while in model 2 , the coefficient for milk became less precise $(-0.0086$, $\mathrm{p}=0.1295$ for the estimate of modifier effect). Compared with the results from Table $4, \mathrm{Ca}, \mathrm{Li}, \mathrm{Zn}, \mathrm{Cu}$, and $\mathrm{Rb}$ remained significantly correlated with DF severity, while $\mathrm{Mg}$, $\mathrm{Al}$, and $\mathrm{Ba}$ lost their significance when the Bonferroni correction was used. The associations detected in the multivariate analysis shown in Table 5 also did not change appreciably: specifically, the estimates for $\mathrm{F}^{-}(0.0760 \pm 0.0345$; $\mathrm{p}=0.028), \mathrm{Cu}(0.216 \pm 0.067 ; \mathrm{p}=0.001), \mathrm{Rb}(0.0503 \pm 0.0137$; $\mathrm{p}<0.0001), \mathrm{Al}(-0.0012 \pm 0.0006 ; \mathrm{p}=0.044)$, and Ca did not change $(-0.0236 \pm 0.0146 ; \mathrm{p}=0.10)$, though its statistical significance decreased in a few cases.

Analysis by age-specific groups (specifically, stratifying into two groups for children younger than 10 years old and for individuals aged 10 years old or older) also did not change the study results. The base effect of $\mathrm{F}^{-}$remains strongly significant $(\mathrm{p}<0.0001)$ in both age groups: 0.1085 for children younger than $10 y e a r s$ old and 0.1819 for individuals aged $10+$. The effect of milk became $-0.047(\mathrm{p}=0.11)$ and $-0.091(\mathrm{p}=0.018)$ for the two age groups, respectively. Similarly, the modifying effect of milk became $-0.0058(\mathrm{p}=0.307)$ and -0.0127 $(\mathrm{p}=0.077)$, respectively.

An additional sensitivity study is inspired by the analysis involving the principal components. $\mathrm{F}^{-}$can be excluded from the list of elements contributed to the principal components, and then the principal components could be used as co-factor controlling correlations with other metals. The result for $\mathrm{F}^{-}$effect with the six principal components is similar: $0.181 \pm 0.023 ; \mathrm{p}<0.0001$. Since the means of PCs are zero, 
this estimate can be compared to the base effect of $\mathrm{F}^{-}(0.151)$. Thus, the effect of $\mathrm{F}^{-}$could be a little larger (approximately one standard error effect) after controlling for concentrations of other elements.

\section{Discussion}

DF is caused by exposure to excessive $\mathrm{F}^{-}$in water used for drinking and cooking purposes, and also by $\mathrm{F}^{-}$intake from other sources, e.g. foods high in $\mathrm{F}^{-}$such as tea, seafood, certain wines, grains, vegetables, and fish (Doull et al., 2006; Grobler et al., 2001). DF is the most widespread and long-recognized health effect of $\mathrm{F}^{-}$exposure. However, $\mathrm{F}^{-}$ also may cause damages to other organs and systems: for example, skeletal fluorosis (Edmunds and Smedley, 2005) that is characterized by the thickening and increased density of bones, thyroid dysfunction (resulting in slower mental development and lower IQ in children) (Ding et al., 2011) (Xiang et al., 2003), dysfunction of reproductive system (leading to infertility, especially in males due to oligo- or azoospermia and, probably, lower testosterone level) (Chinoy and Narayana, 1994; Ortiz-Pérez et al., 2003), developmental defects in fetuses (GUPTA et al., 1995; Takahashi, 1998), and gastrointestinal problems (nausea, stomach pain, intermittent diarrhea, and flatulence) (Dasarathy et al., 1996). We conducted a study of dental health outcomes among randomly selected households living in several communities of the MER of Ethiopia; our focus on DF was motivated by the fact that it is the most widespread and easily diagnosed condition that can be observed in populations consuming water with excessive $\mathrm{F}^{-}$ concentration.

As we expected, compared with other elements found in the local groundwater, $\mathrm{F}^{-}$was the main contributor to $\mathrm{DF}$ in the study population. While the prevalence of DF in our study was estimated for a relatively young population (having an average age of 17.6 years old), many of these individuals (23.3\%) already had severe DF. This is in agreement with the results of multiple studies in which DF has been described as a disease that begins from birth, when uptake of $\mathrm{F}^{-}$by human skeleton is the highest (Ozsvath, 2009; Whitford, 1999). About half of the absorbed $\mathrm{F}^{-}$is quickly incorporated into developing bone and teeth, where nearly all of the body's $\mathrm{F}^{-}$is found, and the remainder is excreted in the urine (Cerklewski, 1997). Exposure to $\mathrm{F}^{-}$during enamel development causes a dose-related disruption of enamel mineralization resulting in anomalously large gaps in its crystalline structure, excessive retention of enamel proteins, and increased porosity of the teeth (Aoba and Fejerskov, 2002). The high prevalence of DF found in the study population is understandable: $89.9 \%$ of them live in communities having groundwater with $\mathrm{F}^{-}$concentration exceeding the WHO standard $(>1.5 \mathrm{mg} / \mathrm{l})$, and approximately $2 / 3$ of these residents source water for drinking and cooking from the boreholes and dug wells which have the highest levels of naturally occurring chemical contaminants. We also found that the severity of DF increases with age, probably due to the increasing exposure of the organism to excessive $\mathrm{F}^{-}$in water and food.

In our study, the SSSF but not BMI was found to be an independent factor associated with increased severity of DF among the population exposed to $\mathrm{F}^{-}$. Yet excessive weight is rare in the study population among adults, only $11.4 \%$ are overweight or obese. In this and other analyses conducted for populations in this region, the effect of BMI has been found to be inconsistent; its positive association with DF may in part be explained by its strong association with age (i.e., severity of DF increased with age) (Rango et al., 2012). In fact, there are very few data on the role of body weight and BMI in the development of DF. An opposite correlation has been discussed instead suggesting that $\mathrm{F}^{-}$ intake may be associated with weight reduction (Bray, 2004). The correlation between SSSF and $\mathrm{F}^{-}$found in our study in the absence of BMI effect and the role of nutritional status more generally requires further evaluation. One possible explanation for the association we found is that the distribution of fat deposition (i.e., in the upper body) could be hormone-related, and therefore also associated with exacerbation of $\mathrm{F}^{-}$effects on teeth. Indeed, differences across males and females may also be related to hormonal factors (as well as specific gender-related behaviors). Further studies of the role of BMI and gender in DF outcomes (accounting for other factors such as detailed analysis of dietary patterns) are required to better understand these results.

Our study revealed that a more frequent consumption of cow's milk, and longer breastfeeding periods were negatively associated with DF (both independently and as modifiers of the effect of $\mathrm{F}^{-}$). Among the explanations for these results could be the competitive relationship between $\mathrm{Ca}$ (which is present in milk) and $\mathrm{F}^{-}$during the formation of tooth enamel, or alternatively decreased absorption of $\mathrm{F}^{-}$from the gastrointestinal tract in the presence of milk. In other studies, it has been shown that a variety of dietary factors can either increase or decrease the amount of $\mathrm{F}^{-}$that is absorbed (Cerklewski, 1997; Cremer and Büttner, 1970): for example, when $\mathrm{Ca}, \mathrm{Mg}$, Al salts, phosphates, sulfates, and Mo were added to the diet, $\mathrm{F}^{-}$was incorporated into less soluble compounds that can be eliminated through fecal and urinary excretion (Ericsson, 1968; Whitford, 1994).

Regardless of multiple observations of DF worldwide, the exact mechanism behind the development of DF remains unclear. One hypotheses is that during enamel maturation excess $\mathrm{F}^{-}$forms a highly toxic hydrogen fluoride (Sharma et al., 2010) which can easily diffuse through the tooth's cell membrane and dissociate in the cell's cytosol back into its component ions; then, excessive intracellular $\mathrm{F}^{-}$could affect protein synthesis leading to an increased level of protein which is seen in fluorotic enamel (Sierant and Bartlett, 2012). During this process other elements may interfere with the effects of $\mathrm{F}^{-}$; however, to the best of our knowledge, such interactions have not been widely studied. Non- $\mathrm{F}^{-}$elements could also influence $\mathrm{F}^{-}$uptake in the human organism: e.g., they could affect $\mathrm{F}^{-}$absorption from the gastrointestinal tract, thus increasing or decreasing its excretion. Our study found that eleven non- $\mathrm{F}^{-}$elements were correlated with $\mathrm{DF}$ outcomes when included independently or as modifiers of $\mathrm{F}^{-}$effects: namely $\mathrm{Cl}, \mathrm{Ca}, \mathrm{Mg}$, $\mathrm{Li}, \mathrm{Zn}, \mathrm{Al}, \mathrm{Cu}, \mathrm{Rb}, \mathrm{Sr}, \mathrm{Ba}$, and $\mathrm{Tl}$. However, there is a high correlation across those elements in the groundwater of the study communities in the MER (Rango et al., 2012), and understanding these associations, therefore, requires much more study. More generally, many of the world's high- $\mathrm{F}^{-}$districts are underlain by crystalline igneous and metamorphic rocks (e.g., parts of India, Sri Lanka, Senegal, Ghana, South Africa, and Scandinavia) or occur in areas of volcanic and associated hydrothermal activity (Ozsvath, 2009). When the groundwater enters into contact with these rocks, it is often soft and Ca-deficient, which allows for higher $\mathrm{F}^{-}$concentrations when equilibrium with fluorite is attained (Ozsvath, 2006). F can also form strong complexes with Al, B, Be, ferric iron, $\mathrm{SiO}_{2}, \mathrm{U}$, and $\mathrm{V}$, but these constituents may not always be present in groundwater, or the conditions necessary for ensuring their stability may not be reached in natural waters (Hem, 1985).

To deal with the high degree of correlation in concentrations of different elements in the groundwater of the study communities, this research applied several methods of statistical analysis. First, noting that $\mathrm{F}^{-}$is the primary factor affecting dental health in the study population, other elements were analyzed through the prism of their effect on $\mathrm{F}^{-}$-associated DF. Using backward variable selection, four elements other than $\mathrm{F}^{-}$were identified to have the greatest degree of correlation with TFI scores. One of these, Ca, is a major element that has a wellestablished inverse relationship with $\mathrm{F}^{-}$(Ozsvath, 2006), and which was found in our multivariate analysis to be negatively correlated with DF. This is also in agreement with our results regarding the negative correlation between milk (which is high in $\mathrm{Ca}$ ) consumption and TFI scores. Other studies have also shown a significant negative association between Ca intake and tooth loss (Adegboye et al., 2010). Also, Ca is widely used in dentistry, for example, for remineralization of enamel lesions of teeth (as a crème component) to improve dental structure (Zhang et al., 2011). Another element that may have a protective effect on teeth in populations exposed to excess $\mathrm{F}^{-}$is Al. Teeth with 
higher Al level have been shown to have fewer caries on average than teeth with low Al; suggesting its potential "cariostatic" role ( $\mathrm{T}$ et al., 2004). Also, the increased consumption of $\mathrm{Al}$ salts decreases $\mathrm{F}^{-}$absorption in the intestine and increases $\mathrm{F}^{-}$excretion from the body, thus decreasing exposure to $\mathrm{F}^{-}$(Ericsson, 1968; Whitford, 1994).

On the other hand, $\mathrm{Rb}$ and $\mathrm{Cu}$ were found to be positively related to DF outcomes. Rb has affinity to the teeth, especially during the period of tooth formation: it is greatly absorbed by the dentin and tooth enamel (Olsson et al., 1969). Cu-related hypodontia and enamelodentipathia has been described to cause a white discoloration in teeth which could be misdiagnosed as DF (PANEK, 2006). In general, there is very little literature on the dental effects of these elements in humans; however, existing studies suggest that they may play some role in dental health.

Besides the difficulties arising from the high correlation in concentration of different groundwater elements, there are important limitations related to the sampling design of the study. Because children are at increased risk of developing dental fluorosis, the study aimed to include children from the households enrolled in the study. Thus, while the age structure of our sample may be roughly representative of the population given that households were randomly selected, we targeted dental evaluations to children that already had their adult teeth. In addition, not all household members were examined. Thus, our results are not fully representative of the populations of these communities, though sensitivity analyses suggest that the detected associations are consistent across age groups.

Establishing appropriate drinking water standards for $\mathrm{F}^{-}$(i.e., its maximum allowable concentrations) is dependent upon many factors, including climate, diet, and characteristics of the target population (and even within a given region, different subsets of the population may respond differently to the same dose) (Ozsvath, 2009). Some researchers have argued for more stringency than the WHO standards for countries with hot, dry climates (Brouwer et al., 1988), or for the regions where $\mathrm{F}^{-}$content in food is higher than that assumed by WHO (Apambire et al., 1997). While considering the optimization of region-specific standards, it is also reasonable to consider how local diet, water sourcing practices, and consumption of non- $\mathrm{F}^{-}$elements in water may influence health outcomes. Future studies (and, first of all, collection of data) along these lines could provide the additional information needed to improve such guidelines.

A major challenge that remains in better understanding the role of different elements in water and DF outcomes is the high degree of correlation among these elements. The PCA analysis provides some clues regarding the most "influential" combinations of elements contributing to the severity of manifesting DF in populations chronically exposed to $\mathrm{F}^{-}$; however additional research is needed. In future work, the reliability of this PCA model could be tested based on its ability to make out sample predictions of individual TFI scores in nearby locations. To construct such a prediction, one could first determine the principal component values for each individual in a test sample, and, second, use those scores (together with the age) to predict the average TFI score using the model parameters presented in Table 6. If such an approach were found to have a strong predictive power, it could enable more precise prediction of DF severity in populations living in the area of interest than would calculations based on exposure to $\mathrm{F}^{-}$alone.

\section{Conclusions}

In summary, $\mathrm{F}^{-}$was found to be strongly associated with $\mathrm{DF}$ in a sample of over 1000 individuals living in several rural communities of the MER in the Ethiopia. Age, sex, SSSF, and milk consumption (both cow's and breastfed) were found to be correlated with DF outcomes, both as independent factors and through modification of the effects of $\mathrm{F}^{-}$. In addition, several other elements in water were significantly associated with dental health in the study area, suggesting the possibility that DF may be related to multiple contaminant exposures. Additional research is warranted to more effectively isolate these effects, and to understand the mechanisms by which they operate.

Supplementary data to this article can be found online at http://dx. doi.org/10.1016/j.scitotenv.2013.12.087.

\section{Conflict of interest}

JK declares no actual or potential conflict of interest including financial support of the submitted work; no personal or other relationships with people or organizations that could inappropriately influence the work occurred since 2007 and during the period of time during which the research took place.

TR declares no actual or potential conflict of interest including financial support of the submitted work, as well as no persona, or other relationships with organizations or people that could inappropriately influence the work and that occurred since 2007.

IA declares that he has no actual or potential conflict of interest that occurred since 2007, including financial support of the submitted work, personal, or other relationships with people or organizations that could inappropriately influence the work.

BA declares no actual or potential conflict of interest including financial support of the submitted work, personal or other relationships with other people or organizations occurred within three years of beginning the work (i.e., since 2007) that could inappropriately influence the work.

PGMcC declares no actual or potential conflict of interest including financial support of the submitted work, personal or other relationships with other people or organizations occurred within three years of beginning the work (i.e., since 2007) that could inappropriately influence the work.

RBM declares no actual or potential conflict of interest including financial support of the submitted work, personal, or other relationships with people or organizations that could inappropriately influence the work and that occurred since 2007.

$\mathrm{CP}$ declares no actual or potential conflict of interest including financial support of the submitted work, personal or other relationships with other people or organizations occurred within three years of beginning the work (i.e., since 2007) that could inappropriately influence the work.

EW declares no actual or potential conflict of interest including financial support of the submitted work, personal, or other relationships with people or organizations that could inappropriately influence the work and that occurred since 2007.

$\mathrm{CH}$ declares no actual or potential conflict of interest including financial support of the submitted work, personal, or other relationships with people or organizations that could inappropriately influence the work and that occurred since 2007.

AV declares no actual or potential conflict of interest including financial support of the submitted work; no personal or other relationships with people or organizations that could inappropriately influence the work occurred since 2007 and during the period of time during which the research took place.

MJ declares no actual or potential conflict of interest including financial support of the submitted work; no personal or other relationships with people or organizations that could inappropriately influence the work occurred during the period of time during which the research took place (i.e., since 2007).

All authors are independent from funders. There are no other relationships or activities that could appear to have influenced the submitted work.

\section{Role of the funding source}

This work was generously supported by the Duke University Provost's PFIRST (Problem-Focused Interdisciplinary Research-Scholarship Teams) Grants, the Nicholas School of the Environment, the Nicholas Institute for Environmental Policy Solutions, and the Duke Global Health Institute. 
The funders had no influence on the conduct of the results or on the interpretation of results.

"The Corresponding Author has the right to grant on behalf of all authors and does grant on behalf of all authors, a worldwide licence to the Publishers and its licensees in perpetuity, in all forms, formats and media (whether known now or created in the future), to i) publish, reproduce, distribute, display and store the Contribution, ii) translate the Contribution into other languages, create adaptations, reprints, include within collections and create summaries, extracts and/or, abstracts of the Contribution, iii) create any other derivative work(s) based on the Contribution, iv) to exploit all subsidiary rights in the Contribution, v) the inclusion of electronic links from the Contribution to third party material where-ever it may be located; and, vi) licence any third party to do any or all of the above."

\section{Acknowledgments}

Tenalem Ayenew and Addis Ababa University helped to facilitate the work, and helped introduce the survey teams to the water boards in the zones selected for the survey. Dr. Dagemawi Dagem Tewolde (Jimma University) and Zeleke Kebebew expertly led the survey and managed the teams of enumerators and nurses who collected the data. Thanks to our study participants who welcomed us into their homes.

\section{References}

Adegboye AR, Fiehn NE, Twetman S, Christensen LB, Heitmann BL. Low calcium intake is related to increased risk of tooth loss in men. J Nutr 2010;140:1864-8.

Aoba T, Fejerskov O. Dental fluorosis: chemistry and biology. Crit Rev Oral Biol Med 2002;13: $155-70$

Apambire W, Boyle D, Michel F. Geochemistry, genesis, and health implications of fluoriferous groundwaters in the upper regions of Ghana. Environ Geol 1997;33:13-24.

Ayenew T. The distribution and hydrogeological controls of fluoride in the groundwate of central Ethiopian rift and adjacent highlands. Environ Geol 2008;54:1313-24.

Beltrán-Aguilar ED, Barker LK, Canto MT, Dye BA, Gooch BF, Griffin SO, et al. Surveillance for dental caries, dental sealants, tooth retention, edentulism, and enamel fluorosis - United States, 1988-1994 and 1999-2002. In: Morbidity and Mortality Weekly Report 54(03). Centers for Disease Control and Prevention; 2005. p. 1-44.

Bray GA. The epidemic of obesity and changes in food intake: the Fluoride Hypothesis Physiol Behav 2004;82:115.

Brouwer I, De Bruin A, Dirks OB, Hautvast J. Unsuitability of World Health Organisation guidelines for fluoride concentrations in drinking water in Senegal. Lancet 1988;331: 223-5.

Buzalaf M, Levy S. Fluoride intake of children: considerations for dental caries and dental fluorosis; 2011.

Cao J, Zhao Y, Liu J, Xirao R, Danzeng S, Daji D. Brick tea fluoride as a main source of adult fluorosis. Food Chem Toxicol 2003;41:535-42

Cerklawski, Ridlington. Influence of type and level of dietary calcium on fluoride bioavailability in the rat. Nutr Res 1987;7:1073-83.

Cerklewski FL. Fluoride bioavailability-nutritional and clinical aspects. Nutr Res 1997;17: 907-29.

Chinoy NJ, Narayana MV. In vitro fluoride toxicity in human spermatozoa. Reprod Toxicol 1994;8:155-9.

Cremer H, Büttner W. Absorption of fluorides. Monograph series, 59. World Health Organization; 1970. p. 75.

Dasarathy S, Das TK, Gupta IP, Susheela AK, Tandon RK. Gastroduodenal manifestations in patients with skeletal fluorosis. J Gastroenterol 1996;31:333-7.

Ding Y, Sun H, Han H, Wang W, Ji X, Liu X, et al. The relationships between low levels of urine fluoride on children's intelligence, dental fluorosis in endemic fluorosis areas in Hulunbuir, Inner Mongolia, China. J Hazard Mater 2011;186:1942-6.

Doull J, Boekelheide K, Farishian B, Isaacson R, Klotz J, Kumar J. Fluoride in drinking water: a scientific review of EPA's standards, Committee on Fluoride in Drinking Water Board on Environmental Studies and Toxicology, Division on Earth and Life Sciences, National Research Council of the National Academies. Washington, DC: National Academies Press; 2006.

Edmunds M, Smedley P. Fluoride in natural waters. Essentials of medical geology 2005301-29.

Ericsson Y. Influence of sodium chloride and certain other food components on fluoride absorption in the rat. J Nutr 1968;96:60-8.

Fejerskov O. Dental fluorosis: a handbook for health workers; 1988

García-Pérez A, Irigoyen-Camacho M, Borges-Yáñez A. Fluorosis and dental caries in Mexican schoolchildren residing in areas with different water fluoride concentrations and receiving fluoridated salt. Caries Res 2013;47:299-308.

Gizaw B. The origin of high bicarbonate and fluoride concentrations in waters of the Main Ethiopian Rift Valley, East African Rift system. J Afr Earth Sci 1996;22:391-402.
Grobler S, Louw A, Kotze VW. Dental fluorosis and caries experience in relation to three different drinking water fluoride levels in South Africa. Int J Paediatr Dent 2001;11:372-9.

Gupta SK, Gupta RC, Seth AK, Chaturvedi CS. Increased incidence of spina bifida occulta in fluorosis prone areas. Pediatr Int 1995;37:503-6.

Haimanot RT, Fekadu A, Bushra B. Endemic fluorosis in the Ethiopian Rift Valley. Trop Geogr Med 1987;39:209.

Hem JDStudy and interpretation of the chemical characteristics of natural water, vol. 2254. Dept. of the Interior, US Geological Survey; 1985

Hussain J, Hussain I, Sharma K. Fluoride and health hazards: community perception in a fluorotic area of central Rajasthan (India): an arid environment. Environ Monit Assess 2010;162:1-14.

Kaseva M. Contribution of trona (magadi) into excessive fluorosis-a case study in Maji ya Chai ward, northern Tanzania. Sci Total Environ 2006;366:92-100.

Kilham P, Hecky RE. Fluoride: geochemical and ecological significance in East African waters and sediments; 1973.

Kloos H, Haimanot RT. Distribution of fluoride and fluorosis in Ethiopia and prospects for control. Trop Med Int Health 1999;4:355-64.

Mabelya L, König KG, van Palenstein Helderman WH. Dental fluorosis, altitude, and associated dietary factors. Caries Res 1992;26:65-7.

Malde MK, Zerihun L, Julshamn K, Bjorvatn K. Fluoride, calcium and magnesium intake in children living in high-fluoride area in Ethiopia. Intake through food. Int J Paediatr Dent 2004:14:167-74

Malinowska E, Inkielewicz I, Czarnowski W, Szefer P. Assessment of fluoride concentration and daily intake by human from tea and herbal infusions. Food Chem Toxicol 2008:46:1055-61.

Martínez-Mier E, Soto-Rojas AE, Ureña-Cirett JL, Stookey GK, Dunipace AJ. Fluoride intake from foods, beverages and dentifrice by children in Mexico. Community Dent Oral Epidemiol 2003;31:221-30.

McDowell MA, Fryar CD, Ogden CL, Flegal KM. Anthropometric reference data for children and adults: United States, 2003-2006. US Department of Health and Human Services, Centers for Disease Control and Prevention, National Center for Health Statistics; 2008.

Meyer-Lueckel H, Bitter K, Khorrami G, Kielbassa A, Paris S. Relationship of caries and fluorosis in adolescents from high-and low-fluoride areas in Iran. Community Dent Health $2011 ; 28: 248$

Olsson B. Dental findings in high-fluoride areas in Ethiopia. Community Dent Oral Epidemiol 1979;7:51-6.

Olsson KA, Söremark R, Wing KR. Uptake and distribution of rubidium-86 and potassium-43 in mice and rats-an autoradiographic study. Acta Physiol Scand 1969;77:322-32.

Ortiz-Pérez D, Rodŕıguez-Martínez M, Martınez F, Borja-Aburto VcH, Castelo J, Grimaldo JI, et al. Fluoride-induced disruption of reproductive hormones in men. Environ Res 2003;93:20-30.

Ozsvath DL. Fluoride concentrations in a crystalline bedrock aquifer Marathon County, Wisconsin. Environ Geol 2006;50:132-8.

Ozsvath DL. Fluoride and environmental health: a review. Rev Environ Sci Biotechnol 2009;8:59-79

Panek H. Hypodontia and enamelodentinopathies in environment polluted with heavy metals; 2006

Poureslami HR, Khazaeli P, Noori GR. Fluoride in food and water consumed in Koohbanan (KUN-E BANAN), Iran. Research Report Fluoride, 41. 2008. p. 216-9.

Rango T, Bianchini G, Beccaluva L, Ayenew T, Colombani N. Hydrogeochemical study in the Main Ethiopian Rift: new insights to the source and enrichment mechanism of fluoride. Environ Geol 2009;58:109-18.

Rango T, Bianchini G, Beccaluva L, Tassinari R. Geochemistry and water quality assessment of central Main Ethiopian Rift natural waters with emphasis on source and occurrence of fluoride and arsenic. J Afr Earth Sci 2010a;57:479-91.

Rango T, Colombani N, Mastrocicco M, Bianchini G, Beccaluva L. Column elution experiments on volcanic ash: geochemical implications for the main Ethiopian rift waters. Water Air Soil Pollut 2010b;208:221-33.

Rango T, Kravchenko J, Atlaw B, McCornick PG, Jeuland M, Merola B, et al. Groundwater quality and its health impact: an assessment of dental fluorosis in rural inhabitants of the Main Ethiopian Rift. Environ Int 2012:43:37-47.

Reimann C, Bjorvatn K, Frengstad B, Melaku Z, Tekle-Haimanot R, Siewers U. Drinking water quality in the Ethiopian section of the East African Rift Valley I-data and health aspects. Sci Total Environ 2003;311:65-80.

Rozier R. Epidemiologic indices for measuring the clinical manifestations of dental fluorosis: overview and critique. Adv Dent Res 1994;8:39-55.

Sharma R, Tsuchiya M, Skobe Z, Tannous BA, Bartlett JD. The acid test of fluoride: how pH modulates toxicity. PLoS One 2010:5:e10895.

Sierant ML, Bartlett JD. A potential mechanism for the development of dental fluorosis. Interface Oral Health Science 2011. Springer; 2012. p. 408-12.

Tanaka T, Maki K, Hayashida Y, Kimura M. Aluminium concentration in human deciduous enamel and dentin related to dental caries. J Trace Elem Med Biol 2004;18:149-54.

Takahashi K. Fluoride-linked Down syndrome births and their estimated occurrence due to water fluoridation. Fluoride 1998;31:61-73.

Teotia SPS, Teotia M. Dental fluorosis in areas with a high natural content of calcium and magnesium in drinking water - an epidemiological study. Fluoride 1975;8:34-8.

Thylstrup A, Fejerskov O. Clinical appearance of dental fluorosis in permanent teeth in relation to histologic changes. Community Dent Oral Epidemiol 1978;6:315-28.

Viswanathan G, Gopalakrishnan S, Siva Ilango S. Assessment of water contribution on total fluoride intake of various age groups of people in fluoride endemic and non-endemic areas of Dindigul District, Tamil Nadu, South India. Water Res 2010;44:6186-200.

Whitford G. Effects of plasma fluoride and dietary calcium concentrations on GI absorption and secretion of fluoride in the rat. Calcif Tissue Int 1994;54:421-5.

Whitford GM. Fluoride metabolism and excretion in children. J Public Health Dent 1999:59:224-8. 
WHO (World Health Organization)In: Fawell J, Bailey K, Chilton J, Dahi E, Fewtrell L Magara Y, editors. Fluoride in drinking water. Cornwall, UK: IWA Publishing Group; 2006a. p. 31-6. (134 pages).

WHO (World Health Organization). Guidelines for drinking-water quality: first addendum to third edition. Recommendations, vol. 1; 2006b.
Xiang Q, Liang Y, Chen L, Wang C, Chen B, Chen X, et al. Effect of fluoride in drinking water on children's intelligence. Fluoride 2003;36:84-94.

Zhang Q, Zou J, Yang R, Zhou X. Remineralization effects of casein phosphopeptideamorphous calcium phosphate crème on artificial early enamel lesions of primary teeth. Int J Paediatr Dent 2011;21:374-81. 